\title{
Congress compromises on rules governing NIH policies
}

Washington. Under the cloud of a threatened presidential veto, Congress last week agreed on a compromise package of legislation affecting the National Institutes of Health (NIH) that moderate many of its most controversial incursions into biomedical research politics. Although public attention on the bill, known as the "NIH Revitalization Amendments of 1992", has been focused on its attempt to overturn the current federal ban on fetal tissue research (see sidebar), scientific groups have been equally concerned about its language on a variety of subjects from women's health research to conflict of interest. Until last week, the House of Representatives draft defined scientific misconduct and conflict of interest in research and prescribed detailed procedures to prevent it.

In a conference last week, the House and Senate agreed on a compromise bill on which they are expected to vote this week. Administration officials say that President George Bush intends to veto the bill, both for its fetal tissue provisions and for a host of other clauses that he considers a preemption of the administration's own policymaking process. But Congressional supporters of the bill are optimistic that they will be able to overturn a veto. Among its provisions, the joint bill would:

Forbid the Secretary of the Department of Health and Human Services (HHS) from arbitrarily halting research on ethical grounds, as long as it has been peer-reviewed and approved by an Institutional Review Board. To withhold funding for such a project, the HHS secretary would have to get the approval of an independent ethics advisory board. On the other hand, the secretary would also have to demonstrate that any surveys of sexual behaviour (such as the three the administration has cancelled under political pressure in recent years) will help reduce sexually transmitted disease or otherwise improve health. To placate conservative Senator Jesse Helms (Republican, North Carolina), the bill bans two sex surveys that have been political footballs for years.

- Establish the Office of Scientific Integrity as an independent entity within HHS. This would remove it from NIH, which NIH director Bernadine Healy has also recommended.

- Require HHS to develop a new definition of scientific misconduct. In its own bill, the House had actually supplied a definition, but researchers attacked it as impossibly broad. The conference report instead requires HHS to set up an independent "Commission on Scientific Integrity" to advise
HHS on the definition and other aspects of policing scientific misconduct. A section that would have forced journals to retract research that had been shown in error (see Nature 357, 2 \& 7; 7 May 1992) was deleted in the conference agreement.

- Require regulations defining and protecting against financial conflict of interest in NIH-funded research. NIH has been working on such regulations for several years; Healy says the draft regulations now being prepared for release are essentially in line with the congressional requirement. Contrary to earlier versions of the bill, the conference agreement would allow institutions to develop their own procedures to comply with the NIH regulations.

Ensure that NIH has regulations protecting whistleblowers from retaliation. In practice, this would mean that institutions receiving NIH funding would have to put in place guidelines to protect those who had made scientific misconduct allegations "in good faith" and cooperated with investigators.

- Establish criminal penalties for activists who attack animal facilities. This would include anyone who took or released animals, stole documents or damaged the facilities. Punishment would include fines, imprisonment and restitution. However, the bill would also require NIH to develop a plan to minimize its use of animals and to conduct research on animal alternatives.

Research groups last week seemed generally relieved at the final language. "If it had been up to us, it would have been more like 15 lines than 30 pages", says David Moore, a congressional lobbyist for the American Association of Medical Colleges. "But overall, it's not a bad compromise." Healy, however, attacked the bill as both unnecessary and intrusive. "We don't think we need to be reauthorized", she says. The administration "has a number of concerns with the bill. Whether it was the fetal tissue part that pushed them over the top [to a veto], I don't know." Nevertheless, Healy says that NIH can live with the consequences should Congress collect enough votes to overturn the expected veto and turn the legislation into law.

"On issues like women's health and minority health, we've already moved ahead of the bill", she says. Since the legislation has been in the making for more than three years, NIH has already had ample opportunity to respond to many of the congressional concerns that are behind the language. Many of the other provisions in the compromise language, Healy says, either reflect moves already afoot at NIH or extend current programmes.

Christopher Anderson

\section{Researchers reject fetal tissue banks}

Washington. In an eleventh-hour bid to derail congressional legislation overturning his ban on research involving the transplantation of fetal tissue, President George Bush promised last week to set up a "fetal tissue bank" to collect material from miscarriages and ectopic pregnancies - the only sources of fetal tissue that avoids the political minefield of the abortion issue.

But research and health groups denounced the move as a "cruel hoax". They said that little tissue from such fetuses would be usable for medical purposes or research and that viable tissue would be nearly impossible to obtain. "It simply would never work", Eugene Redmond, director of Yale University's fetal tissue transplant programme, wrote in a letter to Congress last week.

In explaining the tissue bank proposal, James Mason, assistant secretary of the Department of Health and Human Services, estimated that of the 200,000 or so spontaneous abortions that occur in US hospitals each year, about 2,000 could be used in a tissue bank for research. But Redmond cited a study of fetal tissue from spontaneous abortions in three New York hospitals to argue that such usable abortions occur, on the average, only 1.4 times a year in each hospital. A team of three or four specialists need to be on hand to dissect the brain region in the fetus. "We would have to station such a team on call at each hospital at any time a pregnant woman came in with a threatened miscarriage," he wrote. Spontaneous abortions usually occur for a reason that renders the tissue unusable for research or transplant.

Redmond also rejected the White House suggestion that, once a bank is established, the fetal tissue could be perpetuated and grown in cell lines. Noting that such a process would require new fundamental knowledge of molecular and genetic mechanisms, he emphasized that "these techniques do not exist and cannot be legislated into existence". 